\begin{tabular}{ll}
\hline 資 & 料 \\
\hline
\end{tabular}

日本に京けるゴキブリ類の研究の記録補遺

\section{Notes on the past knowledge of the} cockroaches in Japan

A bibliographical survey

\section{朝 比 奈 正二 郎* \\ Syoziro Asahina}

筆者は，既に $(1955 ， 1960 ， 1961 ， 1963)$ ，本邦に於て 明治以降に行なわれた邦産ゴキブリ類の，主として分類 学的記述の整理を試みたが，其の後主に明治の後年に於 て，我が国の昆虫研究者が邦産のゴキブリ類をどのよう に扱つて来たかに興味を持ち，「博物之友」或いは「昆虫 世界」等の雑誌などから当時の知見を抽出してみた。こ こに記述する内容は，従つて，純分類学的な処置を論ず るものでなく，主として和名によつて，当時の知見の整 理を試みたものと了解していただければよく，最後にゴ キブリ類の方言等にも少しくふれた。これらについて筆 者の思いちがい或いは見落しの文献等を御認めの方があ つたならば，御教示を下さるように御願いする。ここで は松村氏の日本昆虫学（1898）以後素木氏が新種を記載 はじめる頃まで(1906 08)の間のものを主に扱つた。

手許に欠けた文献を参照するに際しては，農技研の長 谷川仁氏を煩わした。ここに謝意を表する次第である。

\section{邦産ゴキブリ類の種類に関する知見}

以下，柏年順に記述して，これに筆者の解釈を附して ゆくことにする.

既に記したように，邦産ゴキブリ類各種の名称を，方 言でなく，標準和名の意味に於て用いたのは

1898 (明治31年) 松村松年,「日本昆虫学」p.56 のゴ キブリ (Periplaneta americana)，チャバネアブラムシ (Phyllodromia germanica), オオアブラムシ(Panesthia angustipennis) を以て嚆矢とする.

1902 (明治35年) 岐阜の名和昆虫研究所より出されて いた「昆虫世界」に,「土佐産の虫報」を連載していた武 内護文氏（高知県土佐郡在住）は，第 5 報（昆虫世界， $6(60) ， 326-329)$ に於て，“蜚蜉科（一）ゴキブリ， （二）チャバネアブラムシ，(三）オオアブラムシ”を

国立予防衛生研究所衛生昆虫部

Department of Medical Entomology, National Institute of Health, Tokyo
挙げ，“此の中（一）（二）注最しも普通にして（三） は山中に産するも其の数多きも見ず，一種山中及び海浜 の沙上に産して形色（二）に酷似するも，其幼虫と成虫 の少[し]異なるものあり" と述心゙た.この最後に記され たものは今日のモリチャバネかヒメチャバネであるう.

同じ「昆虫世界」上に $6(63) ， 441-445)$ 長野㐘次郎 氏は“虫蠏につきて，上”上して当時発行されたUS DA（北米合衆国農務省）の昆虫部助手 Marlatt 氏の解 説書を紹介し〔抄訳?]，つづいてその下（6(64)，490493）に於て，“本邦に産する普通の蜚蝹の学名につき ては，余之を確言する能はず，恐らくは未だ学名を有 せざる種にあらざるなきか, 或る一二の書には Periplaneta americana を当てあれども，こはその標本を比 較寸れば一目の下に錯誤に出でしものなることを弁別す ベし，その胸部注割合い小さきを以て…「ヤマトゴキ ブリを指す? ]，…台南県に産する一種にアメリカナ と一致するものあり〔ワモンであるうう，又大阪地方に産 して，普通のものと異れる一種あり，形状よくアメリカ ナに類似すれども少しく小さし[クロゴキブリか?，台 北県に産する一種には P. australasiae と符合するもの あり〔コワモンであるう〕．而して普通産のチヤバネア ブラムシは確かに，Ectobia (Phyllodromia) germanica なり〔モリチャバネも含むか??”。更に敵虫，駆除法 についても䓵述がある。

1903 (明治36年) 名和靖氏は昆虫に関寸る随感随想第 三回（昆虫世界，7(73)，384-386）中に於て，ゴキブリ の分布についてと題し，“蕬にはただ二種についてその 分布を示さんとす”，として，甲種（ゴキブリ）に属す るものは，岐阜郡(全部)，石川県鹿島郡，京都府天田郡 及与謝郡，鳥取県東伯郡に，乙種（ムナビロゴキブリ） は愛知県宝飯郡及渥美郡，静岡県志太郡，千葉県長生郡 鳥取県西伯郡，島根県那賀郡，徳島県勝浦郡，大分県南 海部郡，宮崎県（農事試験場）に分有するとした。 又 卵塊と今成虫の聥図を示している汸，これを見れば甲種 は今日のヤマトゴキブリであり，乙種“ムムナビロゴキ ブリ”と新称したものは明らかにクロゴキブリである

1904 (明治37年) 小竹浩氏は皇太子殿下奉献中等教育 昆虫標本詳解（其 9)（昆虫世界，8（81），182-185，第 5 版口絵) に於て，“117. アブラムシ (Periplaneta americana L.) ”を図説し，その記載中に，“雄は翅長 く全く腹部を覆へども，雌は翅短く腹部の後半を露出 す”と記した，その図版中の写真令稀を見ても，これ がヤマトゴキブリを指すものであることは明膫である。 この中に“前胸大きく恰も基器䘮冠りたる如く見ゆる を以てゴキブリ又はゴキカブリト云う”とあるが，この 碁器 (碁石入れ) は正しくは御器 (食器) と解す心゙きだ 
$(206)$

衛 生 動 物

あろうと思う。

同誌 (82)，225-229 に小森省作氏は，第一回岐阜県昆 虫分布調查（7）を解説しているが，ゴキブリ科中に， ““ゴキブリ (Stylopyga concinna Hag.) ”, “チャネバ ゴキブリ (Phyllodromia germanica Steph.) ), “オオ ゴキブリ (Panesthia angustipennis Illig.) " の3 種を あげた。“ゴキブリ”は古が短翅であるという記述よ りみればヤマトゴキブリを指し，“チャバネゴキブリ”, は“山林原野にも亦尠からず”とあつてモリチャバネ を混じており，“オオゴキブリ”は挿図を見ても今日の ものと同じ物であろら。

この年に出版になつた松村博士の日本千虫図解第 1 巻 垱当時の昆虫分類学の標準よなつたものであろうが，こ れには“ゴキブリ (Stylopyga concinna Hag.) ”即ち ヤマトゴキブリ，“コバネゴキブリ（Stylopyga orientalis)” 即ちトウヨウゴキブリ，“チャバネゴキブリ (Phyllodromia germanica Steph.) " 当然千ャバネとモ リチャバネの混合, “オオゴキブリ (Panesthia angustipennis Illig.) "が図説された。

同じ年佐々木忠次郎氏は，東洋学芸雑誌，12月号に於 て、「蛪蛳につきての説」として屋内害虫であるチャバネ ゴキブリのことを解説した，更に1905（明治38年）少年 :向けの月刊雑誌「少年」 1 月号にも同様な記述をした. [この雨文献は直接参照し得なかつた].

矢野宗幹氏は「亚蝓につきて」と題し（博物之友，5 (25)，104-105）上記の佐々木氏が虫螑の文字を全然チ ヤバネゴキブリのみにあてたことは不当であるとし，自 身豊前に於て観察した所より：

ゴキブリ：常に屋内に多数に生じ，屋外に於ては之を 見ず，食物等を害す。

チャバネゴキブリ：稀に屋下に見らるるむ多くは森林 の枯葉下又は原野の石下にあり， 幼虫又汢成虫にて越冬す。

とし，前者はアブラムシ又はゴキブリ（筑後）として知 られるもので, 估ヶ木氏が後者を室内害虫として挙げた のは不思議であるとした，今日から見れば，佐ヶ木氏の ものはその頃も都市だけに限られて棲息したと思はれる 真のチャバネゴキブリで，一方知野氏のチャバネゴキブ リは，全くモリチャバネゴキブリであつたと推定でき る. 又知野氏の“ゴキブリ”も恐らくクロゴキブリを 指したものではないか上思われる。

小熊捍氏（博物之友，5(25)，145）は“矢野氏の「蜚 螊二就キテ」に就きて”上題し，東京に於ては[真正 の]チャバネゴキブリは佐々木氏の云う如く室内害虫で あると記した。 之に対し矢野宗幹氏（博物之友，5(27)， 209-210) は“再びゴキブリに就て。”と題し，豊前に於
ては“ゴキブリ〔?クロゴキブリ〕”は大害虫で，その 被害の程度はチャバネ〔即ちモリチャバネ】上同日の論 ではないと記した。

1906 (明治39年) 矢野宗幹氏は重水て, ゴキブリ類に 就きて（上）之題し（博物之友，6 (30)，27-29)，その 後の資料に基ついて，和名についての文献上の知見を総 攬し，和名についてはゴキブリという名称をこの類の総 称にするのが妥当である上した，引続き，ゴキブリ類に 就きて（下）（博物之友，6(32)，138-141）に於ては，九 州産の種類として,

1.む称びろごきぶり (学名未詳) 豊前, 豊後, 筑前, 肥後，薩摩〔この和名は名和氏 (1903)より由来するもの と思われる。これ注明らかにクロゴキブリを指す.」

2. 学名末詳 肥後熊本 (山崎又雄氏) [本種について は全然記述なく，今日の何種索指すか全く不明.]

3.おおごきぶり Punesthia angustipennis 筑前鞍手 郡 (小南迅氏)

4.ちゃばねごきぶり Phyllodromia germanica 筑 前, 豊前, 豊後, 肥後ここれは会部モりチャバネと見る ベきであろう.]

をあげ，又屋内種の問題にふふ，土佐の武内護文氏報ず る所に“チャバネゴキブリは 1 市或いは 1 村中稀に発生 し其家に汢大群蟻集して加害大なるも前者[ゴキブリ]の 如く凡ての家に発生するにあらず”とあり，又疑氏自 身が]“昨年八月大分より竹田に入らんとして, 茶店の䈏 辺を見るに幾十百の小虫右往左往するものあり，就きて 是を視るにチャバネゴキブリなり云々”とあるのは共に 果して真のチャバネであるか不明，矢張りむしろモりチ ヤバネの可能性が強い.なお他の屋内種として，ゴキブ リ〔ヤマトゴキブリ]及びムナビロゴキブリ[クロゴキブ リ]を挙げ,前者は本邦の東部に後者は西南部暖地に見ら れるとした。

次に野外種上して，“千ャバネゴキブリ”が森林の秙 葉下等に多数見られるのを述べているが，これはくり返 し註記したように全くモリチャバネゴキブリに外ならな い.ゴキブリ[ヤマト]とムナビロ[クロ]も共に野外 に見られることが述べてあるが，これは今日でも特に夏 期には両種が戸外に見られることがあつて，むしろ当然 なことであろう。

最後に矢野氏はゴキブリ類の和名の整理索試み，

1. Phyllodromia germanica L. チャバネゴキブリ [夷はモリチャバネを含む]

2. Panesthia angustipennis Illig. オオゴキブリ

3. Stylopyga concinna Hag. 才ホクロゴキブリ (矢 野氏改称）〔ヤマトゴキブリ]

4. S. orientalis L. コバネゴキブリ〔トウヨウゴキ 
ブリであるが日本には産しない筈】

5. 学名不明 ムネビロゴキブリ[実はクロゴキブリ]

6. Periplaneta americana L. ワモンゴキブリ〔果し て当時台湾以外の本邦に産したか不明）

7.P. australiasie [!] F. ヒメワモンゴキブリ[果 してコワモンゴキブリが台湾以外の本邦の地に産したか どうか不明]

8. P. palita Walk. ダイワンゴキブリ（松村）〔何を 指寸加不明]

9.P. semicincta Wk. オビゴキブリ（松村）

重ねて矢野氏は，ゴキブリ追記（一）として（博物之 友，6(33)，228）に，青森の新渡戸稲雄氏よりの「当地 にも兵舎の所在地に Stylopyga concinna の繁殖するも のを採集せることあり云云」及び，丸亀の箕浦忠愛氏の ムナビロゴキブリ[クロゴキブリ]の幼虫らしきものを 「本種は丸亀にては普通に戸棚押入れにありて加害甚し きものに候」という記録を加えた。

1907 估々木忠次郎氏は三度“チャバネアブラムシ”, の記事を記し（昆虫学雑誌 (東京), 2(5), 221), 〔真正. の]チャバネゴキブリの生態，駆除法を記した。駆除法 には種油をひいたトラップなど述べてあるが，依然屋内 種のチャバネゴキブリ一点張りであった.

この頃より素木博士の新種の記載がはじまつたが，同 氏の報文は其の後のす心゙てに亘つても，これまでここに 記述したような和名，学名，生態，分布等の論議には全 く無関心で，凡そこれらを参照した形跡の見られないの は誠は不思議といら外はない，従つてこの後の邦人研究 者による若干の論文もあるが，台湾種についての外は， 見るべき内地座ゴキブリの分類，分布，生態等の記述は 極めて䬥々たるものとなつて，以上縷述した問題は混乱 のまま遂に最近に至つたと云つても過言でない．

\section{ゴキブリの名称方言古記録等について}

表記の問題については現在手許に十分な資料はないが 二三心覚えを書きとめておきたいと思う。

上述した知野宗幹氏の報文（博物之友，6(30)，27-29 1906) に於ては :

“名称：コノ類ノ和名トシテ八あぶらむしノ名比較 的古ク且ツ広ク使用セラレ,ごきあらひむし是二次グ (倭 訓の琹, 言海, 言葉の泉二拠ル). 古名トシテつのむし ノ名アリ．和名抄ニ出ヅルモ虫蜕二訓ジタルモノニシテ 漢名ガ正確二使用セラレタルカ否カ知ルベカラザルナ リ，其他方言二就テ八本草綱目啓蒙二詳ナリ。”とあ b.

小野蘭山著, 重訂本草綱目啓蒙, 第 4 巻, 三十七, 化 生虫部の“蜚蠊”項を引用すれば：“蜚蠊 ツノムシ (和名鈔), アブラムシ, ゴキカブリ（筑前, 筑後, 伯
州，雲州）ゴキクラヒムシ (勢州)，アマメ（同上，山 田，薩州，肥前），ゴキカブラウ (肥前)，ゴゼムシ (土州), 平入アマメ(紀州)，アマクヒムシ (越前)，ゴキアラヒム シ (丹後) , [中略]

“夏秋八間霆辺㴻簐中二甚ダ多シ，長サ一寸余径六七 分, 翼アリ，夜飛全身褐色，微黑油色ノ如ク兼テ油臭了

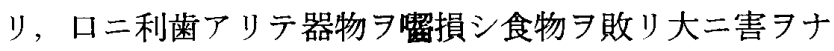
ス, 一種形小サク四分許ノ長サニテ翼モ備ル者アリ, 紀 州ニテアマメ[ト]云故二尋常ノアブラムシ 同所ニテ平 八アマメト云”［下畧]

矢野氏自身（1906）で当時確認された[黒色大型種の ?]方言は次のようである.

ごぜむし(土佐)，あぶらむし(豊前)，あまめ(鹿巟島) ごっきこぶり (肥後)，ごきかぶり(筑前筑後).

又ちやばねごきぶり [モリチャバネを指すか？]に就 いては：

あぶらむし(士佐)，いご（豊前，筑前，或いは普通種 の小型の幼虫も含む).

更に本草綱目啓蒙にある“一種形小サク四分許/長サ ニシテ云云”とあるものを疑氏はチャバネゴキブリ [恐らく正しくはモリチャバネ]と考えた。

矢野氏はこの類の総称として，夥しい種類より成る半. 翅目の蚵虫との混合をさけるために，“アブラムシ”を 排し，ゴキカブリより転じた“ゴキブリ”を以てすべき ことを提唱した，更に上記本草綱目㤵蒙に於ける記述を 見ても，この名は Blattidae に所属する黒色の Periplaneta 属の種を総称していたと解釈す心く、“ゴキブリ”. の名を〔松村氏等の如く】特定の 1 種の和名とすること は不可であると論じた。

更に進んで，支那で “蜚蜲”之称するものは何を指す かについては，矢野氏も本草綱目の記述より見て，日本 と共通の単一の種を指すものでなく，この漢字もゴキブ リ類の総称であろうと考えた.

Bernard E. Read (1941) : Chinese Materia Medica, Insect drugs，134-138を見ると：

“蟅显 (Cockroach)” と “䖯蠊 (Flying cockroach)”, とがでているが，前者は Cybister 属のゲンゴロウ(上海 産材料)とサツマゴキブリ (香港産材料), 及び Polyphagidae のゴキブリ (北京産材料) を含んでいて，又後者は Blattidae のゴキブリ 3 種と，チャバネゴキブリ及びオ オゴキブリを含むものとなつている，いずれにしろ，こ のよらな特別な「漢字の研究」は別として，今日ゴキブ リ類を指すのにこんな複雑な漢字を用いる必要は全くな いであろらと思う。

本稿を整えるに当つては昭和 39 年度厚生科学研究費 の一部を使用した。 